\title{
Motivasi Belajar Mahasiswa dalam Pembelajaran Daring di Masa Pandemi Covid-19
}

\author{
Arie Anang Setyo1, Muhammad Syahrul Kahar², Rahmatullah Bin Arsyad ${ }^{3}$, \\ Muhammad Fathurrahman ${ }^{4}$, Hilman DJafar ${ }^{5}$, Wenny Hulukati ${ }^{6}$, Abd. Kadir Husain ${ }^{7}$ \\ 1,2,3,4,5 Universitas Muhamadiyah Sorong \\ ${ }^{6,7}$ Fakulat Ilmu Pendidikan Universitas Negeri Gorontalo
}

Email: arieanangsetyo.ums@gmail.com

\begin{abstract}
Pandemi Covid-19 berdampak pada dunia pendidikan. Adanya wabah virus corona ini menghambat kegiatan belajar mengajar yang biasanya berlangsung secara tatap muka dan mengharuskan proses pembelajaran harus dari rumah atau School from Home (SFH). Tujuan dari penelitian adalah untuk mengetahui motivasi Pembelajaran Selama Pandemi Covid-19. Adapun metode yang diterapkan dalam penelitian ini adalah menggunakan pendekatan Kuantitatif, dimana jumlah sampel 41 orang mahasiswa yang ada di Universitas Muhammadiyah Sorong. selain itu, Teknik pengumpulan data menggunakan aplikasi google form dan dianalisis menggunakan Microsoft excel, adapun jenis surveinya menggunakan skala likert. Hasil penelitian ini mengemukakan bahwa implementasi pembelajaran daring dapat memberikan dampak dalam peningkatan pemahaman mahasiswa selama pelaksanaan pembelajaran meliputi beberapa aspek yakni perhatian, pemahaman, kemampuan dan motivasi berada pada kategori cukup dan baik dalam menerima materi yang disampaikan. Oleh karena itu, pembelajaran daring dapat memberikan nuansa pembelajaran tersendiri yang dapat berdampak pada peningkatan pengetahuan dan pemahaman mahasiswa selama pembelajaran.
\end{abstract}

Kata Kunci: Pembelajaran Daring; Pandemik Covid-19; Motivasi Belajar

\begin{abstract}
ABSTRACK
The Covid-19 pandemic has an impact on the world of education. The existence of this corona virus outbreak hinders teaching and learning activities that usually take place face-to-face and requires the learning process to be from home or School from Home (SFH). The purpose of the study was to determine the motivation for learning during the Covid-19 Pandemic. The method applied in this research is to use a quantitative approach, where the sample size is 41 students at the Muhammadiyah University of Sorong. In addition, the data collection technique uses the Google Form application and is analyzed using Microsoft Excel, while the type of survey uses a Likert scale. The results of this study suggest that the implementation of online learning can have an impact on increasing student understanding during the implementation of learning covering several aspects, namely attention, understanding, ability and motivation in the sufficient and good category in receiving the material presented. Therefore, online learning can provide its own nuances of learning that can have an impact on increasing student knowledge and understanding during learning.
\end{abstract}

Keywords: Online Learning; Covid-19 Pandemic; Motivation to learn 
(C) 2021 Arie Anang Setyo, Muhammad Syahrul Kahar, Rahmatullah Bin Arsyad, Muhammad Fathurrahman, Hilman DJafar, Wenny Hulukati, Abd. Kadir Husain

Under The License CC BY-SA 4.0

\section{PENDAHULUAN}

Pandemi Covid-19 berdampak pada dunia pendidikan. Adanya wabah virus corona ini menghambat kegiatan belajar mengajar yang biasanya berlangsung secara tatap muka dan mengharuskan proses pembelajaran harus dari rumah atau School from Home (SFH) (Marbun, 2020). Berdasarkan data UNICEF, WHO dan IFRC dalam COVID-19 Prevention and Control in Schools (Maret, 2020) menyebut bahwa ketika situasi persebaran virus semakin cepat maka sekolah harus ditutup dan proses pendidikan harus tetap berjalan melalui kegiatan pembelajaran online dengan menggunakan berbagai media. Data UNESCO (2020) menyebut 1,5 miliar siswa dan 63 juta guru di tingkatan sekolah dasar hingga menengah di 191 negara yang terdampak pandemi Covid-19, sesuatu yang tidak pernah terjadi sebelumnya. Situasi ini memaksa Pemerintah melalui Menteri Pendidikan dan Kebudayaan mengeluarkan instruksi melalui Surat Edaran Kemdikbud No 4 Tahun 2020 mengenai Pelaksanaan Pendidikan Dalam
Masa

Darurat Coronavirus

Disease (Covid-19).

Berdasarkan Edaran Kemendikbud tersebut kemudian masing-masing Lembaga Pendidikan di seluruh Indonesia dan terkhusus di Papua Barat menjalankan instruksi kemendikbud dengan menerapkan proses pembelajaran secara online. Seperti yang kita ketahui bahwa pembelajaran online merupakan salah satu solusi agar proses pembalajaran tetap berjalan di era pandemi covid 19 (Firman 2020), Risalah dkk (2020). Pembelajaran online mampu mengurangi resiko terhadap penularan covid 19 kepada guru, siswa dan juga orang tua yang notabenenya merupakan orang yang beresiko tinggi pada penyebaran virus covid 19 (Harususilo, 2020), (Pahan \& Fitriani, 2020). Agar proses pembelajaran pada era pandemi dapat berjalan dengan baik maka sangat penting untuk bagaimana setiap Lembaga Pendidikan mendesain pelaksanaan pembelajaran dengan baik, dimana dengan desain yang baik tersebut akan memudahkan lembaga Pendidikan menentukan kebutuhan-kebutuhan seperti apa yang diperlukan untuk melaksanakan proses pembelajaran (Marbun, 2020).

\section{E-ISSN: 2716-0580}


Berdasarkan observasi ditemukan bahwa masing Lembaga-lembaga pendidikan yang ada di papua menerapkan berbagai macam metode pembelajaran online yang dipadukan dengan mediamedia pembalajaran online yang mudah, praktis, dan terjangkau sesuai dengan kondisi pandemi covid 19. Oleh karenanya pada penelitian ini penulis ingin mengetahui seperti apakah model-model pembelajaran yang digunakan selama masa pandemi covid 19, fasilitas-fasilitas atau tools apa yang digunakan selama pembelajaran di era pandemi covid 19, kendala-kendala apakah yang dihadapi guru dan siswa selama pembelajaran daring, dan untuk mengetahui kelebihan dan kekurangan pembelajaran daring. Berdasarkan permasalahan-permasalahan yang ada pada proses pembelajaran di era pandemi covid peneliti ini melakukan penelitian tentang survei motivasi Pembelajaran Selama Pandemi Covid-19.

\section{METODE PENELITIAN}

Adapun metode yang diterapkan dalam penelitian ini adalah menggunakan pendekatan Kuantitatif, dimana jumlah sampel 41 orang mahasiswa yang ada di Universitas Muhammadiyah Sorong. selain itu, Teknik pengumpulan data menggunakan aplikasi google form dan dianalisis menggunakan Microsoft excel, adapun jenis surveinya menggunakan skala likert.

\section{HASIL DAN PEMBAHASAN}

\section{Hasil penelitian}

Adapun hasil penelitian yang diperoleh tentang survey pembelajaran daring seperti pada Gambar 1.

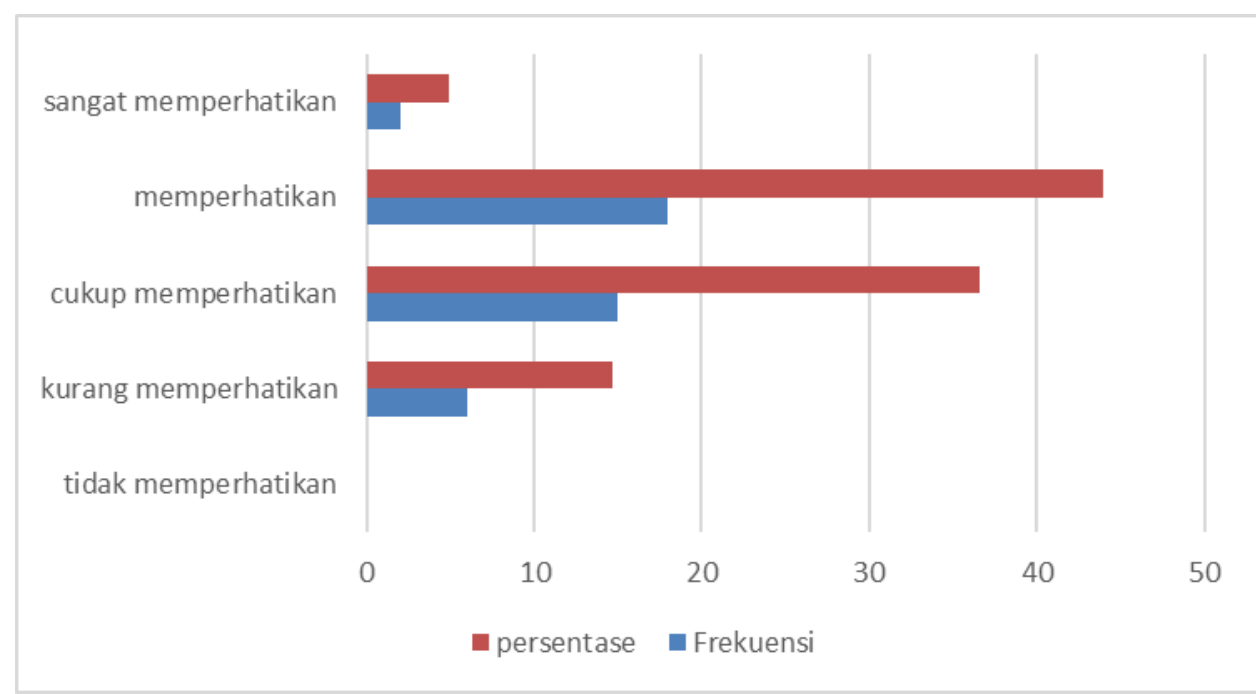

Gambar 1. hasil angket mahasiswa berkaitan dengan perhatian mahasiswa selama proses pembelajaran 
HaL. 13-20

Gambar diatas menunjukkan bahwa menjelaskan bahwa pembelajaran daring persentase tertinggi berkaitan dengan dapat berdampak positif dalam jumlah mahasiswa yang memperhatikan pembelajaran. Sepadan dengan (Crews \& selama proses pembelajaran adalah $43,9 \%$ atau 18 dari 41 responden. persentase terendah adalah $4,9 \%$ pada kategori sangat memperhatikan, sedangkan yang berada pada kategori kurang dan cukup memperhatikan berturut-turut adalah $14,6 \%$ dan 36,6\%. Dari uraian tersebut dapat disimpulkan bahwa secara umum Parker, 2017; Mather \& Sarkans, 2018), mengemukakan bahwa pelaksanaan pembelajaran daring memberikan kebermafaatan dalam menyediakan akses untuk semua pebelajar, sehingga dapat mengurangi hambatan dan mempermudah proses pembelajaran.

mahasiswa memperhatikan apa yang berkaitan dengan pemahaman terhadap disampaikan dosen selama proses instruksi yang diberikan dosen saat pembelajaran daring, walaupun dengan pembelajaran daring seperti pada gambar 2 . kategori perhatian terendah adalah kurang memperhatikan. Mustofa, dkk. (2019)

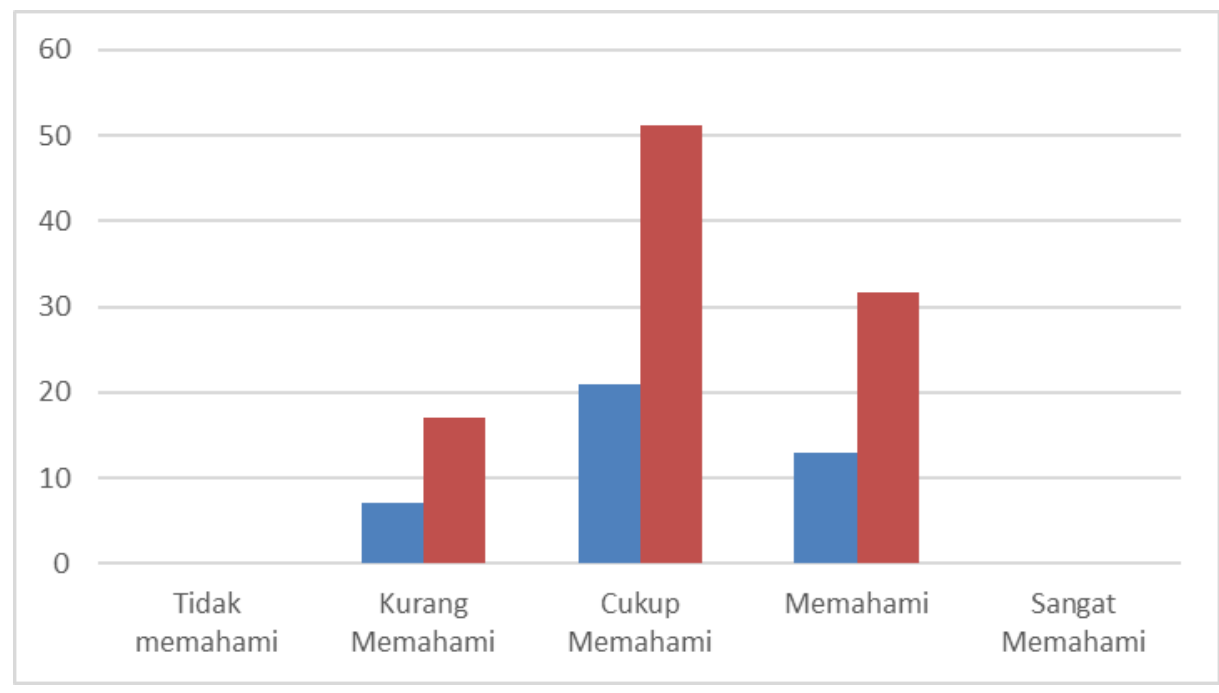

Gambar 2. hasil angket pemahaman terhadap instruksi

Dari data diatas menjelaskan bahwa memahami, cukup memahami dan respon mahasiswa berkaitan dengan memahami dengan persentase masingpemahaman mereka selama pembelajaran masing $17,1 \%$, 51,2\% dan $31,7 \%$. Hasil daring berada pada kategori kurang tersebut dapat ditarik kesimpulan bahwa 
selama pelaksanaan pembelajaran daring, berkaitan dengan kemampuan mahasiswa rata-rata mahasiswa masih memahami dalam mengerjakan tugas yang diberikan intruksi yang disampaikan oleh dosen. dosen saat pembelajaran daring seperti Disisi yang lain hasil angket mahasiswa gambar 3.

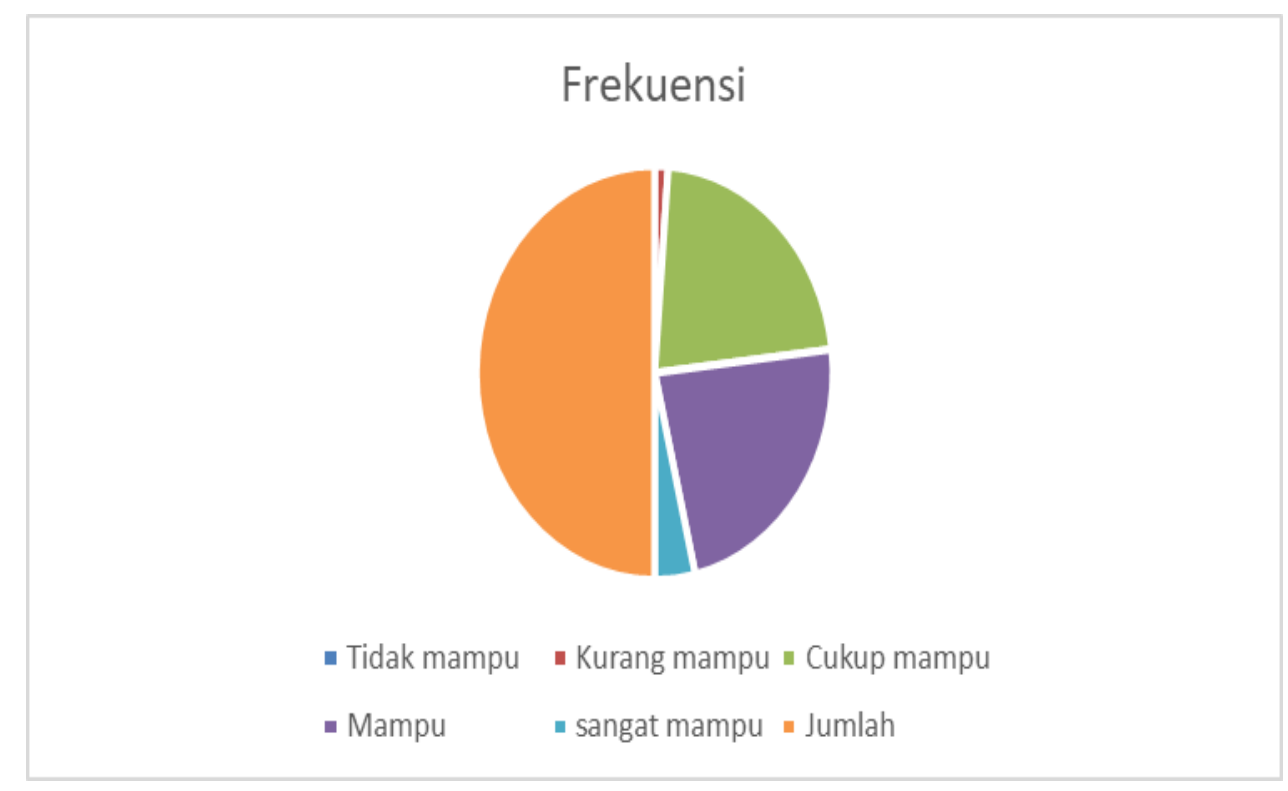

Gambar 3. hasil angket kemampuan mahasiswa dalam mengerjakan tugas

Data hasil angket mahasiswa berkaitan dengan kemampuannya dalam mengerjakan tugas yang diberikan dosen selama pembelajaran daring yang disajikan pada gambar 3, menunjukkan bahwa persentasi terendah berada pada kategori kurang mampu dan sangat mampu yaitu $2,4 \%$ dan $7,3 \%$, dengan persentase tertinggi berada pada kategori mampu atau 46,3\%. Sehingga dapat disimpulkan bahwa selama pembelajaran daring diterapkan, sebagian besar mahasiswa cukup mampu atau bahkan mampu dalam mengerjakan tugas yang diberikan oleh dosen. Menurut Hung et al
(2010) menjelaskan bahwa optimalisasi pembelajaran daring erat kaitannya dengan penyiapan ketersediaan pembelajaran yang dapat memberikan kepercayaan pada pengimplementasian media informasi misalnya internet. selain itu dapat menumbuhkan kesadaran dalam pembelajaran secara mandiri dan mampu meningkatkan motivasi belajar dalam peningkatan pembelajaran. Kemudian pada hasil angket mahasiswa berkaitan dengan motivasi untuk bertanya dan berdiskusi selama pembelajaran daring seperti pada gambar 4

\section{E-ISSN: 2716-0580}




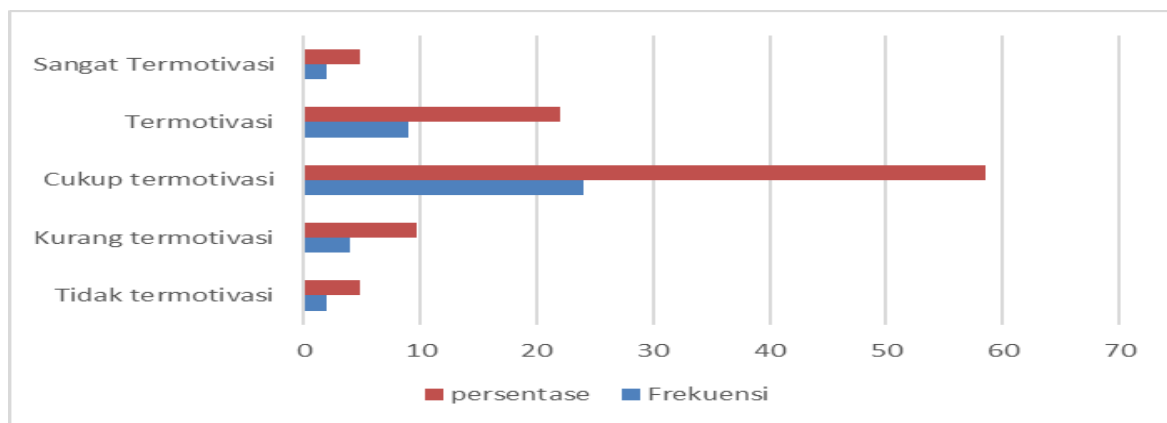

Gambar 4. hasil angket motivasi untuk bertanya dan berdiskusi selama pembelajaran daring

Berdasarkan gambar diatas menunjukkan bahwa motivasi mahasiswa untuk bertanya dan berdiskusi selama pembelajaran daring bervariasi, dari tidak termotivasi sampai sangat termotivasi. Data tersebut juga memberikan gambaran bahwa persentase terendah adalah $4,9 \%$ yaitu pada kategori tidak termotivasi dan sangat termotivasi. Dengan persentase tertinggi yaitu 58,5\% berada pada kategori cukup termotivasi. Hasil tersebut dapat ditarik kesimpulan bahwa selama pembelajaran daring diterapkan, secara umum mahasiswa merasa cukup termotivasi untuk bertanya dan berdiskusi. Hal ini sesuai dengan Siagian (2015) mengemukakan bahwa motivasi dan semangat belajar berhubungan dengan peningkatan kualitas belajar. Menurut (Nurhayati, 2019; Tahar \& Enceng, 2006) memaparkan bahwa terdapat keterkaitan antara kemandirian belajar dengan hasil belajar baik jika dilaksanakan melalui pembelajaran langsung maupun pembelajaran daring atau jarak jauh.

\section{Pembahasan}

Berdasarkan hasil penelitian yang telah dijelaskan diatas, maka terdapat 4 aspek dalam mengukur keterlaksanaan pembelajaran dimasa pandemi Covid-19 diantaranya sebagai berikut: Perhatian mahasiswa dalam mengikuti pembelajaran menunjukkan adanya persentase yang relatif tinggi atau jika dikategorikan berada pada sangat memperhatikan. Disisi yang lain aspek ini kemudian memunculkan harapan bahwa pembelajaran daring mampu menumbuhkan perhatian mahasiswa dalam mengikuti proses pembelajaran.

Sesuai dengan penelitian Sari dan Rusmin, (2018) mengemukakan bahwa atmosfer pembelajaran melalui pembelajaran daring dapat menumbuhkan motivasi belajar mahasiswa, dimana penciptaan ini sangat erat kaitannya dengan proses pembelajaran yang dilaksanakan dengan luring. 
Selanjutnya pada aspek pemahaman terhadap instruksi dosen dalam pembelajaran masih memperlihatkan ketercukupan rata-rata pemahaman mahasiswa dalam menerjemahkan segala bentuk informasi yang disampaikan oleh dosen meskipun menggunakan via daring dengan kategori memahami. Hasil ini sejalan dengan penelitian Werdayanti, (2008) menjelaskan bahwa pelaksanaan pembelajaran dapat memberikan pengaruh yang cukup signifikan pada tingkatan kemampuan pendidik dan penerapan fasilitas belajar sehingga dapat menumbuhkan motivasi mahasiswa.

Kemudian pada aspek kemampuan mahasiswa dalam mengerjakan tugas juga memperlihatkan adanya pemenuhan kebutuhan dengan kategori mampu atau tergolong pada persentase yang tinggi. Maka dari itu, pelaksanaan pembelajaran daring tetap juga mampu menjaga kondisi pembelajaran tetap berjalan dengan baik. Sejalan dengan Sardiman, (2012) menjelaskan bahwa pemberian motivasi dan semangat belajar yang tinggi dalam mengikuti pembelajaran dapat menimbulkan ketekunan kepada mahasiswa sehingga dapat mempermudah mahasiswa dalam menghadapi kesulitan-kesulitan belajar. selain itu, pada aspek motivasi mahasiswa selama pembelajaran daring menunjukkan adanya semangat akan pelaksanaan pembelajaran yang diikuti dengan kategori cukup termotivasi yang menggambarkan bahwa mahasiswa mampu mengkondisikan pembelajaran selama pandemi sehingga mampu meningkatkan kemampuan dan pemahaman mereka terhadap materi yang diberikan. Menurut Sardiman, (2012) mengemukakan bahwa motivasi belajar perlu dimiliki oleh mahasiswa agar dapat melihat seberapa besar tingkat motivasinya sehingga dapat menentukan kualitas tindakan dalam menyelesaikan tugas yang diberikan.

\section{SIMPULAN}

Berdasarkan hasil Penelitian yang telah dipaparkan, maka dapat disimpulkan bahwa pelaksanaan pembelajaran daring dapat meningkatkan dan menumbuhkan motivasi belajar mahasiswa selama proses belajar. Disamping itu, wujud peningkatan motivasi ini dibarengi dengan tumbuhnya kemauan untuk tetap melaksanakan diskusi kelompok, bertanya, selama pembelajaran berlangsung sehingga dapat berdampak pada pemahaman mahasiswa selama mengikuti proses pembelajaran. Oleh karena itu, pelaksanaan pembelajaran

E-ISSN: 2716-0580 
daring dapat tetap dilaksanakan dengan baik meskipun dengan keterbatasan yang dimiliki.

\section{REFERENSI}

AECT. (1977). The Definition of educational technology. Washington: AECT

Crews, J., \& Parker, J. (2017). The Cambodian Experience: Exploring University Students' Perspectives for Online Learning. Issues in Educational Research, 27(4), 697719.

Firman, F. (2020). Dampak Covid-19 terhadap Pembelajaran di Perguruan Tinggi. BIOMA: Jurnal Biologi dan Pembelajarannya, 2(1), 14-20.

Harususilo, Y. E. (2020). Work From Home "mengajar dari rumah".

Marbun, P. (2020). Disain pembelajaran online pada era dan pasca covid19. CSRID (Computer Science Research and Its Development Journal), 12(2), 129-142.

Mather, M., \& Sarkans, A. (2018). Student Perceptions of Online and Face-toFace Learning. International Journal of Curriculum and Instruction, 10(2), 61-76.

Mustofa, M. I., Chodzirin, M., Sayekti, L., \& Fauzan, R. (2019). Formulasi Model Perkuliahan Daring sebagai Upaya Menekan Disparitas Kualitas Perguruan Tinggi. Walisongo Journal of Information Technology, 1(2), 151. https://doi.org/10.21580/wjit.2019.1.2. 4067.

Risalah, A., Ibad, W., Maghfiroh, L., Azza, M. I., Cahyani, S. A., \& Ulfayati, Z.

Pedagogika.fip@ung.ac.id $\quad$ P-ISSN: 2086-4469
A. (2020). Dampak Pandemi Covid19 Terhadap Kegiatan Belajar Mengajar Di Mi/Sd (Studi Kbm Berbasis Daring Bagi Guru Dan Siswa). Jiees: Journal Of Islamic Education At Elementary School, 1(1), 10-16.

Sari, Dewi Permata dan Rusmin, A. R. (2018) "pengaruh iklim kelas terhadap motivasi belajar peserta didik di sman3 tanjung raja," Jurnal PROFIT Kajian Pendidikan Ekonomi dan Ilmu Ekonomi 5, no. 1 : 80-88

Sadirman. (2012) Interaksi dan Motivasi Belajar Mengajar. Jakarta: PT Raja Grafindo Persada.

Siagian, R. E. F. (2015). Pengaruh Minat dan Kebiasaan Belajar Siswa terhadap Prestasi Belajar Matematika. Formatif: Jurnal Ilmiah Pendidikan MIPA, 2(2), 122-131. https://doi.org/10.30998/formatif.v2i 2.93.

Tahar, I., \& Enceng. (2006). Hubungan Kemandirian Belajar dan Hasil Belajar pada Pendidikan Jarak Jauh. Jurnal Pendidikan Terbuka Dan Jarak Jauh, 7(2), 91101.-0758-9.

Tune Sumar, W. (2020). Pengelolaan Kelas dalam Meningkatkan Motivasi Belajar Siswa. Jambura Journal of Educational Management, 1(1), 4959.

https://doi.org/10.37411/jjem.v1i1.10 5

Werdayanti, Andaru. (2008). "Pengaruh Kompetensi Guru dalam Proses Belajar Mengajar di Kelas dan Fasilitas Guru Terhadap Motivasi Belajar Siswa," Dinamika Pendidikan 3, no. 1. 